\title{
Microwave-Induced Fast Decalcification of Rat Bone for Electron Microscopic Analysis: An Ultra- structural and Cytochemical Study
}

\author{
Dimitrius Leonardo PITOL ${ }^{1}$ \\ Flavio Henrique CAETANO² \\ Laurelúcia Orive LUNARDI ${ }^{2}$ \\ ${ }^{1}$ Department of Morphology, Stomatology and Physiology, School of Dentistry of Ribeirão Preto,
University of São Paulo, Ribeirão Preto, SP, Brazil
${ }^{2}$ Department of Biology, Institute of Biosciences, São Paulo State University, Rio Claro, SP, Brazil
}

\begin{abstract}
Bone decalcification is a time-consuming process. It takes weeks and preservation of the tissue structure depends on the quality and velocity of the demineralization process. In the present study, a decalcification methodology was adapted using microwaving to accelerate the decalcification of rat bone for electron microscopic analysis. The ultrastructure of the bone decalcified by microwave energy was observed. Wistar rats were perfused with paraformaldehyde and maxillary segments were removed and fixed in glutaraldehyde. Half of specimens were decalcified by conventional treatment with immersion in Warshawsky solution at $4^{\circ} \mathrm{C}$ during 45 days, and the other half of specimens were placed into the beaker with $20 \mathrm{~mL}$ of the Warshawsky solution in ice bath and thereafter submitted to irradiation in a domestic microwave oven ( 700 maximum power) during $20 \mathrm{~s} / 350 \mathrm{~W} / \pm 37^{\circ} \mathrm{C}$. In the first day, the specimens were irradiated 9 times and stored at $40^{\circ} \mathrm{C}$ overnight. In the second day, the specimens were irradiated 20 times changing the solution and the ice after each bath. After decalcification, some specimens were postfixed in osmium tetroxide and others in osmium tetroxide and potassium pyroantimonate. The specimens were observed under transmission electron microscopy. The results showed an increase in the decalcification rate in the specimens activated by microwaving and a reduction of total experiment time from 45 days in the conventional method to 48 hours in the microwave-aided method.
\end{abstract}

Key Words: decalcification, ultrastructure, microwaves, pyroantimonate, bone, maxilla.

\section{INTRODUCTION}

One of the most difficult problems in electron microscopy is to prepare the calcified tissue preserving it in the state as close as possible to that of the living tissue. The preservation of tissue structures and their interrelations depend on the quality and velocity of demineralization. This process usually involves immersion of the specimens in acid solutions for weeks or months (1). These prolonged periods of exposure to decalcifying fluids cause tissue swelling and the bone matrix can undergo hydrolysis $(2,3)$. Several attempts have been made to accelerate the decalcification process and the decalcifying fluids of choice should pro- duce minimal damage to the tissue. Some decalcification protocols described in the literature are fast but, the morphologic preservation is compromised (4). The most commonly used decalcifying fluid for ultrastructural studies is the ethylenediaminetetraacetic acid (EDTA), whose chelating action promotes tissue decalcification, while preserving its structure (5-7). Warshawsky and Moore (7) using a diluted solution of EDTA buffered with $\mathrm{NaOH}(\mathrm{pH} 7.2)$ turned the medium isotonic and less aggressive to the tissues. This decalcification method, though efficient, is time-consuming (nearly 3 weeks), depending on the specimen size (8). Some variations in EDTA decalcification protocols have been proposed, i.e., changing time or using agitation, vacuum

Correspondence: Dimitrius Leonardo Pitol, Departamento de Morfologia, Estomatologia e Fisiologia, Faculdade de Odontologia de Ribeirão Preto, USP, Avenida do Café s/n 14040-904 Ribeirão Preto, SP, Brasil Tel: +55-16-3602-4094. Fax: +55-16-3630-0999. e-mail: dimipitol@yahoo.com.br 
infiltration or some ultrasonic cleaner to accelerate decalcification $(9,10)$. Microwaving have been used in electron microscopy successfully to accelerate the fixating agent's action (11) and preserve the antigens in immunocytochemical studies (12). In the present study, the decalcification methodology proposed by Warshawsky and Moore (7) has been adapted using microwaving to accelerate the decalcification process of rat bone for electron microscopic analysis.

\section{MATERIAL AND METHODS}

\section{Calibration of the Microwave Oven}

The methodology for calibration of the microwave oven was a modification of the method described by Login and Dvorak (9). A conventional microwave oven (Brastemp Model BMP 40 EGA, Manaus, AM, Brazil) with a fixed rotary plate, maximum power output of $700 \mathrm{~W}$ and operating frequency of $2450 \mathrm{mHz}$ was used. A glass beaker containing $100 \mathrm{~mL}$ of distilled water was pre-heated for 2 min to warm up the magnetron. The water was replaced by $100 \mathrm{~mL}$ fresh distilled water. Two percent Giemsa/agar blocks $(0.5 \mathrm{~cm})$ were prepared by completely dissolving the electrophoresis-bars agar (North-Strong, Rockville, MD, USA) in saline and adding Giemsa solution (Sigma Chemical, St. Louis, MO, USA) to the liquid agar (final concentration: $0.5 \%$ ). The Giemsa/agar solution was poured into flat embedding molds and allowed solidifying. The resulting block was immersed in $5 \mathrm{~mL}$ of fixating or decalcifying solution in 35-mm plastic tissue culture dishes located at various positions on the floor of the microwave with $100 \%$ power output. The color change of the Giemsa/ agar blocks served to monitor temperature change during fixation or decalcification. Placing the blocks in different locations on the floor of the oven and irradiating them intended to determine the best position of the specimen during microwave fixation or decalcification.

\section{Fixation}

Wistar rats weighing $200 \mathrm{~g}$ were anesthetized with sodium pentobarbital and perfused with $4 \%$ paraformaldehyde in buffer phosphate via ascending aorta. The upper jaw was removed and cut into two fragments $(1.3 \times 0.5 \mathrm{~cm})$, which were placed in $2.5 \%$ glutaraldehyde solution in buffer phosphate $0.1 \mathrm{M}$ and irradiated in a the microwave oven $\left(15 \mathrm{~s} / 550 \mathrm{~W} \pm 40^{\circ} \mathrm{C}\right)$.

\section{Decalcification}

After fixation, one of the fragments was decalcified following the conventional methodology using $8.5 \%$ Warshawsky solution at $4^{\circ} \mathrm{C}$ with constant agitation and daily changes of the solution. The second fragment was also decalcified in $8.5 \%$ Warshawsky but using microwave energy to accelerate the process. The microwaved specimens were placed in a glass beaker containing $20 \mathrm{~mL}$ of the decalcifying solution, which was immersed in ice bath, irradiated during $20 \mathrm{~s} / 350 \mathrm{~W} /$ $\pm 37^{\circ} \mathrm{C}$. Another beaker containing $100 \mathrm{~mL}$ of distilled water was placed on the left side of the oven. In the first day, a total of 9 irradiations were performed and the specimens were stored overnight at $4^{\circ} \mathrm{C}$ in the decalcifying solution without agitation. In the second day, these microwaved fragments were submitted to a new irradiation totalizing 20 baths, the solution and ice being changed at every bath. After two irradiations, the water in the beaker placed on the left side of the oven was renewed by fresh distilled water.

After the decalcification and independently of the method used, the fragments were washed during $12 \mathrm{~h}$ in $0.1 \mathrm{M}$ sodium cacodylate buffer, $\mathrm{pH}$ 7.4. Tissue fragments were fixed during $2 \mathrm{~h}$ to for $4^{\circ} \mathrm{C}$ in $2.5 \%$ glutaraldehyde in $0.1 \mathrm{M}$ sodium cacodylate buffer, $\mathrm{pH}$ 7.4. The fragments were postfixed in $1 \%$ osmium in buffer collidine-Syn $0.1 \mathrm{M}, \mathrm{pH} 7.4$, during $2 \mathrm{~h}$ at room temperature, and subsequently contrasted in block with $1 \%$ uranile in $0.05 \mathrm{M}$ sodium maleate buffer, $\mathrm{pH}$ 5.2, during $2 \mathrm{~h}$ at room temperature. The fragments were processed by routine method and embedded in epon and analyzed with a transmission electron microscope (CM100, Philips, Eindhoven, The Netherlands).

\section{Cytochemistry for Calcium Detection}

After decalcification with constant agitation or microwaving, the specimens were washed during 30 min with potassium acetate buffer $\mathrm{pH} 7.4$ and immersed in a fixating solution containing $3 \%$ glutaraldehyde in 40 $\mathrm{mM} \mathrm{KH} \mathrm{PO}_{4}$ (pH 7.4) during $5 \mathrm{~min}$. Next, they were rinsed in the same buffer for $15 \mathrm{~min}$. Thin tissue slices were incubated during $1 \mathrm{~h}$ in a $2 \%$ of aqueous potassium pyroantimonate solution and $\mathrm{OsO}_{4}, \mathrm{pH} 9.0$ at $4^{\circ} \mathrm{C}$.

After post-fixation, the specimens were rinsed 3 
times in a potassium acetate buffer $\mathrm{pH} 7.4$ during $30 \mathrm{~min}$ to remove unreacted reagent. Next, they were dehydrated in methanol and embedded in Araldite. Ultra-thin sections were counterstained with lead citrate during $1 \mathrm{~min}$ and examined with the electron transmission microscope.

\section{RESULTS}

The methodology of this study yielded fast and morphologically satisfactory results. The microwaved maxillary fragments showed accelerated decalcification compared to the original methodology by Warshawsky and Moore (7). Within a short period (48 h) the fragments were ready to be processed for transmission electron microscopy, while the specimens submitted to

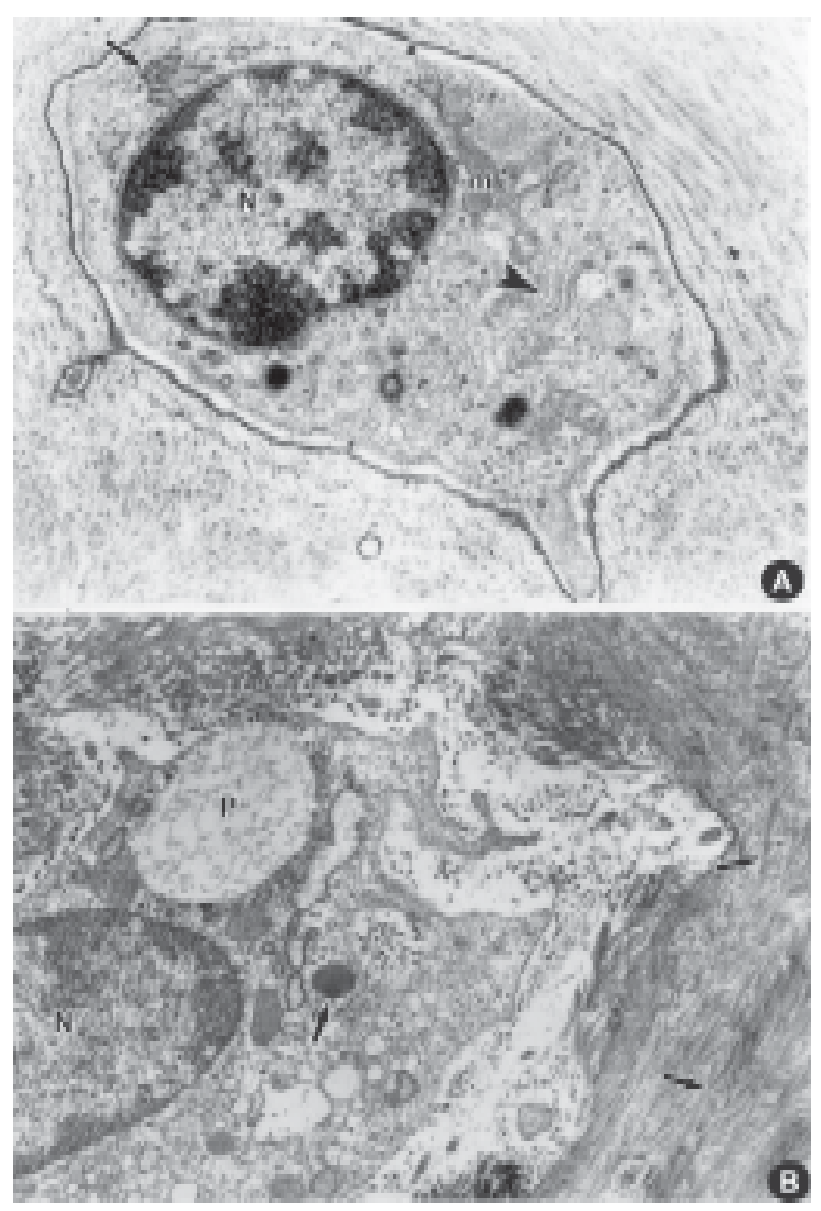

Figure 1. A = Ostoecyte after microwave decalcification: nucleus; (n); endoplasmic reticulum (arrow); Golgi complex (arrowhead); mitochondria (m) (X17000). B = Osteoclasts in phagocytosis after microwave decalcification: (n) nucleus; (p) phagossome; (arrowhead) lysosome; (arrow) collagen fibers (X21000). the conventional treatment reached the satisfactory conditions for processing only after $\mathbf{4 5}$ days.

Morphologically, both methodologies produced similar outcomes (Figs. 1A and 2A). The ultrastructural analysis of the microwaved bone tissue, which was decalcified within $48 \mathrm{~h}$, showed well preserved cells and bone matrix. Figure 1A shows the osteocytes inside the lacunae and also a good preservation of their organelles, such as Golgi complex, granular endoplasmic reticulum and mitochondria. One of the characteristics of good preservation of the decalcified bone tissue is the presence of the osmiophilic lamina surrounding the lacunae. This lamina seems to be equal the borders in brush formed by crystallites that are projected from the osteocyte to the bone. In Figure 1B, the osteoclasts were observed phagocyting the decalcified matrix. In the area of extracellular matrix, collagen fibers appear well preserved, without evidences of calcified matrix.

The cytochemistry of calcium detection also presented good results (Figs. 2B and 2C). Figure 2B

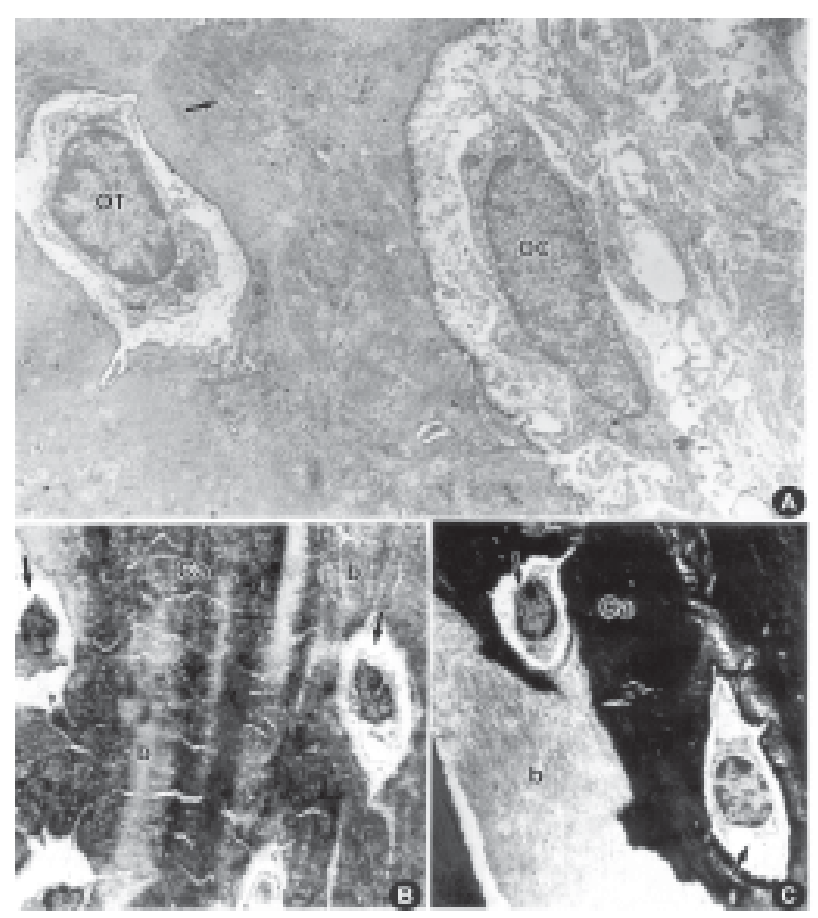

Figure 2. $\mathrm{A}=$ Bone matrix decalcified by immersion: collagen fibers (arrow); osteocyte inside the lacunae (OT); osteoclasts (OC) $(\mathrm{X} 10.000) . \mathrm{B}=$ Remaining $\mathrm{Ca}$ identified by $\mathrm{K}-$ pyroantimonate technique after microwave decalcification; $\mathrm{C}=$ Bone matrix decalcified by immersion: (arrow) osteocyte; (b) demineralized matrix; (Ca) residual calcium (X1700). 
shows a microwaved bone tissue fragment with a small amount of calcium in the matrix. On the other hand, a great amount of calcium was detected in the matrix of the fragments decalcified using the traditional method.

\section{DISCUSSION}

Regardless of the solution used, methods of decalcification share their characteristic of being accelerated when stirred either mechanically or electrolitically using electrodes. Gonçalves and Olivério (1) used an electric decalcification technique with alternate current, increasing the decalcification rate in approximately 3 times compared to the traditional method. According to these authors, this method increases the diffusion of the chelating agent promoting an acceleration of the whole process. In the present study, there was a 30 -fold increase in the decalcification process compared to the traditional method when the material was irradiated in microwave oven.

The energy produced by the microwaves generated in a domestic oven interacts with the dipolar molecules by imparting kinetic energy and altering the electric fields. This energy induces a dielectric fields leading to a rapid oscillation of a dipolar molecule at about $180^{\circ} \mathrm{C}$, generating heat that is rapidly distributed homogeneously within the tissue $(14,15)$.

Some authors $(16,17)$ have suggested that microwaving induces a temperature raise enhancing decalcification by diffusion of the decalcifying solution. Other authors $(18,19)$ have advocated that the action of microwaving does not increase the diffusion of the decalcified solution but rather promotes a larger disposition of the $\mathrm{Ca}^{2+}$ in this agent due to the formed electromagnetic field.

Temperature raise in the system accelerates the diffusion process. However, a great temperature elevation $\left(55-60^{\circ} \mathrm{C}\right)$ is deleterious to tissue morphology. If calcium loss occurs very fast it is followed by a swelling and hydrolysis of the calcified matrix (19). The great increase of temperature produced in the microwave oven was corrected using ice bath during the fixation of a parathyroid sample (19). In the present methodology, ice bath was used to reduce the temperature raise generated by microwaving during the decalcification process.

The use of anions of the potassium pyrantimonate associated with $\mathrm{OsO}_{4}$ combine with certain cations to form electron-opaque and highly insoluble precipitates. Although there is no doubt that under appropriate conditions potassium pyroantimonate will precipitates other cations its action in hard tissue have been used for the localization of calcium with transmission electron microscope $(1,14)$ In the present study, cytochemistry showed a reduction of residual calcium (less electrondensity) in the bone matrix when microwave was used for irradiation decalcification.

In summary, the results presented herein showed that microwave-aided decalcification seems to be more effective than the traditional method in some aspects: a reduction of period of time of decalcification; a good morphological preservation of the bone tissue and an increase of calcium release using microwaving.

\section{RESUMO}

A preservação da estrutura de ossos é dependente da qualidade e da velocidade em que ocorre o processo de desmineralização. Neste estudo foi observada a ultraestrutura de maxila de rato descalcificada utilizando microondas. Ratos Wistar sofreram perfusão com paraformaldeído e o segmento de maxila retirado e fixado em glutaraldeído. Após esta etapa algumas amostras foram descalcificadas por imersão em solução de Warshawsky durante 45 dias a $4^{0} \mathrm{C}$. Outras amostras foram submetidas a irradiação por microondas (forno de microondas doméstico 700 Watts de potência), durante $20 \mathrm{~s} / 350 \mathrm{~W} / \pm 37^{\circ} \mathrm{C}$. No primeiro dia foram realizadas um total de 9 irradiações e os espécimes foram deixadas posteriormente a $4^{\circ} \mathrm{C}$ por $12 \mathrm{~h}$ na solução descalcificadora sem agitação. No segundo dia, os fragmentos foram submetidos à nova irradiação totalizando 20 banhos, trocando-se a solução e o gelo a cada banho. A seguir algumas amostras foram pós-fixadas com tetróxido de ósmio e outras com tetróxido de ósmio e piroantimonato de potássio. As amostras foram observadas em microscópio eletrônico de transmissão. Os resultados mostraram que o processo de descalcificação ativado por microondas reduziu para 48 h o período de descalcificação, o qual pelo método tradicional ocorre em 45 dias.

\section{ACKNOWLEDGEMENTS}

The authors wish to thank Mrs. Monika Iamondi and Mr. Antonio Teruyoshi Yabuky from the Laboratory of Electron Microscopy of ICB-UNESP, Rio Claro, SP, for their technical assistance.

\section{REFERENCES}

1. Gonçalves RP, Olivério LG .Electrical decalcification of bonnet. Mikroscopie 1965;20:154-156.

2. Lillie RD, Askey A, Greco J, Jacquier Burtner H, and Jones P. Decalcification of bone in relation to staining and phosphatases technics. Am Jm Clin Pathol1951;21:-711-722. 
3. Page KM. Bone and the preparation of bone sections. In: Theory and Pratice of Histological Techniques. Bancroft JD, Stevesns A (Editors). Endinburg: Churchill Livingstone; 1982:306-310.

4. Tornero G, Latta LL, Godoy G Uses of microwave irradiation it goes the histological study of bonnet canaliculi. J Histothechnol 1991;14:27-30.

5. Baird IL, Willian BW, Bockman O. Technique of decalcification suited to electron microscopy of tissues closely associated with bonnet. Anat Rec 1967;159:281-290.

6. Jamur MC, Faraco CD, Lunardi LO, Siraganian RP, Oliver C .Microwave fixation improves antigenicity of glutaraldehyde sensitive antigens while preserving ultrastructural detail. J Histochem Cytochem 1995;43:307-311.

7. Warshawsky H, Moore G .Technique goes the fixation and decalcification of rat incisor it goes electron microscopy. J Histochem Cytochem 1967;15:542-549.

8. Laboux O, Dion N, Chaves VA, Ste-Maria LG, Nanci. Microwave irradiation of ethanol-fixed bone improves preservation, reduces processing time, and allows both light and electron microscopy on the same sample. J Histochem Cytochem 2004;25:1267-1275.

9. Login G, Dvorak AM Methods of microwave fixation goes microscopy. Prog Histochem Cytochem 1994;27:1-120.

10. Rode SM, Faria MR, Monteiro MP. Using microwaves goes the decalcification of mineralized tissues of rat mandibles. Braz Oral Res (Formerly Rev Odontol Univ São Paulo) 1996;10:15-18.

11. Lunardi LO, Britto-Garcia S Ultrastructural analysis of the atrial wall of the rat heart. The comparative study of traditional and microwave fixation methods. Rev Chil Anat 1996;14:51-57.
12. Beil WJ, Login GR, Aoki M, Lunardi LO, Morgan AND, Galli SJ, Dvorak AM. Tumor necrosis factor - alpha content of rat mast cell granulates decreases during early secretion induced by compound 48/80. An ultrastructural immunogold morphometric analysis. Int Arch Allergy Immunol.1996;109:383389.

13. Sanderson C, Radley K, Mayton L. Ethylenediaminetetraacetic acid and ammonium hydroxide for reducing decalcification time. Biotech \& Histochem. 1995;70:12-18.

14. Low DPDP, Beer D, Du Plessis MJ. Microwave histoprocessing of bonnet marrow trephine biopsies. Histochem J 1994;26:487-494.

15. Balatona AJ, Loget R. Decalcification equal accélére reads personal computer-where. Ann Pathol 1989;9:140-141.

16. Reith EJ, Boyde A. The pyroantimonate reaction an transcellular transport of calcium in rat molar enamel Histochemistry 1985;83:539-543.

17. Stan, PH. Calcified tissue. In: Boon ME, Kok LP (Editors) Microwave Cook Book of Pathology. Coulomb Press Leynden: Leinden;1988:264-266.

18. Massa LF, Correa VB, Chavez VA. Immunocytochemical study of amelogenin deposition during the early odontogenesis of molars in alendronate-treated newborn rats. J Histochem Cytochem 2006;54:713-725.

19. Wagenaar F, Kok GL, Broekhuijsen-Davies JM, Pol JMA. Rapid cold fixation of tissue samples by microwave irradiation goes it uses in electron microscopy. Histochem J, 1993; 25:719-725.

Accepted April 23, 2005 